\title{
Ornamental trees and shrubs in green areas of the South-East coast of the Crimea
}

\author{
Irina Potapenko ${ }^{1, *}$, Viktoria Letukhova ${ }^{1}$, and Nikolai Klimenko ${ }^{2}$ \\ ${ }^{1}$ T.I. Vyazemsky Karadag Scientific Station - Nature Reserve of RAS - Branch of A.O. Kovalevsky \\ "Institute of Biology of the Southern Seas of RAS", Nauki str., 24, Kurortnoe, 298188, Feodosia, \\ Republic of the Crimea, Russia \\ ${ }^{2}$ Federal State Budgetary Institute of Science "The Order of the Red Banner of Labour Nikita \\ Botanical Garden - National Scientific Center RAS”, Nititsky spusk, 52, 298648, Nikita, Yalta, \\ Republic of the Crimea, Russia
}

\begin{abstract}
The South-East Coast of the Crimea has been developing as recreational region. Green planting is one of the factors that improve its recreational attraction. So it is important to study cultivated here arboreal trees and shrubs for perfection their assortment for landscape gardening. We analyzed taxonomy and biomorphological structure, botanicgeographical origin of dendroflora, the history of introduction, and the present state of cultivated arboreal plants. At present cultivated dendroflora totals 229 species belonging to 107 genus of 27 families. Magnoliophyta occupies $86,0 \%$ of species diversity and the leading role among them belongs to Rosaceae $(27,4 \%)$, Oleaceae $(6,6 \%)$, Leguminosae $(5,6 \%)$. Pinophyta occupies $14,0 \%$ of species diversity and the leading role belongs to Cupressaceae (50,0\%). Species of Mediterranean flora dominate $(31,4 \%)$. The most of them are well adapted to local climatic and soil conditions and provide "Mediterranean" appearance to cultural landscapes. More than a half $(62,9 \%)$ of the species diversity are deciduous trees $(38,4 \%)$ and shrubs $(24,5 \%)$. The proportion of evergreen plants is lower: coniferous trees $-13,5 \%$, and evergreen shrubs $-13,1 \%$. Selecting assortment of ornamental arboreal trees and shrubs should correspond to their ability to withstand summer drought and winter low temperatures.
\end{abstract}

\section{Introduction}

South-East Coast of the Crimea is an attractive region for recreation because of its geographical position, rather mild climate, picturesque landscapes and sea beaches. A lot of sanatorium, tourist complexes, pensions, wellness centers for children are situated in towns and villages of the region. Most of the recreation complexes have green areas on their territories: parks, gardens, and other green plantings with a number of ornamental trees and shrubs. It is known that parks (green areas) perform various functions: sanitary, health and aesthetic, in some cases - educational and environmental. They are also source

*Corresponding author: ira_potapenko@mail.ru 
of floristic diversity in the region, a testing ground for scientific research, and reserves of valuable, rare, endemic plants of the Crimean natural flora.

We may say that first work on introduction to the Crimea different exotic plants began with Greek colonization. But it's not only about the transfer and acclimatization of plants, but of cultural "Mediterraneanization" the Crimea. The ancient Greek settlers in the Crimea transformed the environment in many ways similar to other parts of the Mediterranean world including various techniques for plating crops on thin calcareous soils, terracing, grapes and cereals, other Mediterranean crops that withstood the local climatic condition survived, e.g. pulses, figs, pistachios, and walnuts [1].

Gardening and landscape architecture in the Crimea has a long history. However, gardens and parks arose here only at the end of the XVIIIth and XIXth centuries after joining the Crimea to Russian Empire (1754) in summer residents of aristocratic elite (mostly in Yalta, Alupka, Gurzuf, Simeiz). Many of them are real masterpieces of landscape architecture and garden art. Talking about landscape gardening and introductive activities it should be mentioned the significant role of Nikita Botanical Garden (NBG) that was established in 1812 on the outskirts of Yalta. The role of the scientific staff of the NBG was to acclimatize Mediterranean and other sub-tropical crops and ornamentals to the Crimea and other warm parts of the Empire. Additionally, a statesponsored program to intensify the cultivation of grapevines and improve wine production was implemented by bringing wine specialists from France. By the end of the century, the Crimea had virtually become Russia's Mediterranean coast, dubbed the Russian Riviera [2]. Thus the "Mediterraneanization" of the Crimea was continued at the period of Russian Empire as well.

Parks of the South-East Coast of Crimea have their own history. The first experiments on introductive work at the beginning of the XIXth century were done by amateur gardeners as a hobby - they imported various ornamental plants into their estates, laying the foundation for spontaneous introduction activity in the region. Most of them were not specialists in biology, gardening or greenery, but they had a fancy of such job. Thus, Cupressus sempervirens L., Platycladus orientalis (L.) Franco, Buxus sempervirens L., Aesculus hippocastanum L., Laurus nobilis L., Cedrus libani A.Rich., C. deodara (Roxb. ex D.Don) G.Don were introduced to the region by "summer residents". But a large-scale green construction began in 50s years of the XXth century in the post-war period, many parks and green zones were created at that time. They occupy significant area and are good examples of landscape gardening of the Soviet period. Some of them nowadays have status of landscape art park-monument of local significance. Green areas play an important role in creating a favorable environment of towns and villages, their esthetical image as well. So the studying of cultivated dendroflora would be useful for solving problems of modern planting greenery in the region.

The first rather complete study of the cultural dendroflora of the Crimea (South-East Cost as well) was the work of G.V. Voinov "Park vegetation of the Crimea" (1930). In the Soviet period cultivated dendroflora of the South-East Coast of the Crimea was studied by scientific stuff of the NBG: G.V. Voinov, G.S. Zakharenko, R.V. Galushko, O.D. Shkarlet, G.D. Yaroslavtsev. Currently, such studies are ongoing. Starting a breeding work on introduction of exotic species and forms in ornamental horticulture it should be taken into account their functional adaptation to new growth conditions [3].

The purpose of the present paper is to research the present state, conditions and history of the formation of cultivated East Crimean coastal arboreal vegetation, and analyze composition of species, taxonomy structure, botanical geographical origin, life forms of dendroflora. We also have studied biological, ecological and ornamental features of introduced and native (Crimean flora) arboreal plants cultivated in green areas of the region. 


\section{Materials and methods}

South-East Coast of the Crimea is the territory of the Black sea coastal strip (from 1 to $10 \mathrm{~km}$ wide) of the southern slope of the Main Ridge of the Crimean Mountains from Alushta in the west to Feodosia in the east. The climate is close to subtropical. But to the east of the region (from Sudak to Feodosia) some its continental features increase, which affects the formation of soil, vegetation, as well as opportunities to cultivate heat-loving plants. The most common for the region are brown soils of dry forests and shrubs, brown carbonate and non-carbonate, brown mountain steppe soils [1, 4-5].

Vegetation of the South-East Coast is a belt (that extends to a height of 350-400 meters) of xerophytic oak-juniper (Quercus pubescens - Juniperus excelsa), oak-pistachio (Quercus pubescens - Pistacia mutica), oak-eastern hornbeam (Quercus pubescens Carpinus orientalis) woodlands and small communities of Pinus brutia Ten. At some places there are shiblyak communities dominated by shrubby forms of Quercus pubescens Willd., Pistacia mutica Fisch. et C.A. Mey, Carpinus orientalis Mill., and species such as Juniperus deltoides R. P. Adams, Crataegus orientalis Pall. ex Bieb., Cotoneaster tauricus Pojark., Rosa corymbifera Borkh., Rhus coriaria L., Cotinus coggigria Scop., Paliurus spina-christi Mill., among others. From west to east, the Mediterranean elements of the flora are fading, while the eastern more xerophytic steppes begin to prevail.

We provided the investigations in towns (Sudak, Feodosia) and settlements (Solnechnogorskoe, Malorechenskoe, Sotera, Rybachye, Kanaka, Morskoe, Novy Svet, Solnechnaya Dolina, Shebetovka, Koktebel), and in arboretum of Karadag Scientific Station (Fig.1). We exemined green areas around schools, hospitals, places of work, residential buildings; along streets and highways; in city parks, boulevards, squares, and others. A special attention was paid to different recreational complexes where the species diversity of cultivated trees and shrubs significantly higher since they are being treated properly by gardeners (the main thing is watering in summer drought).

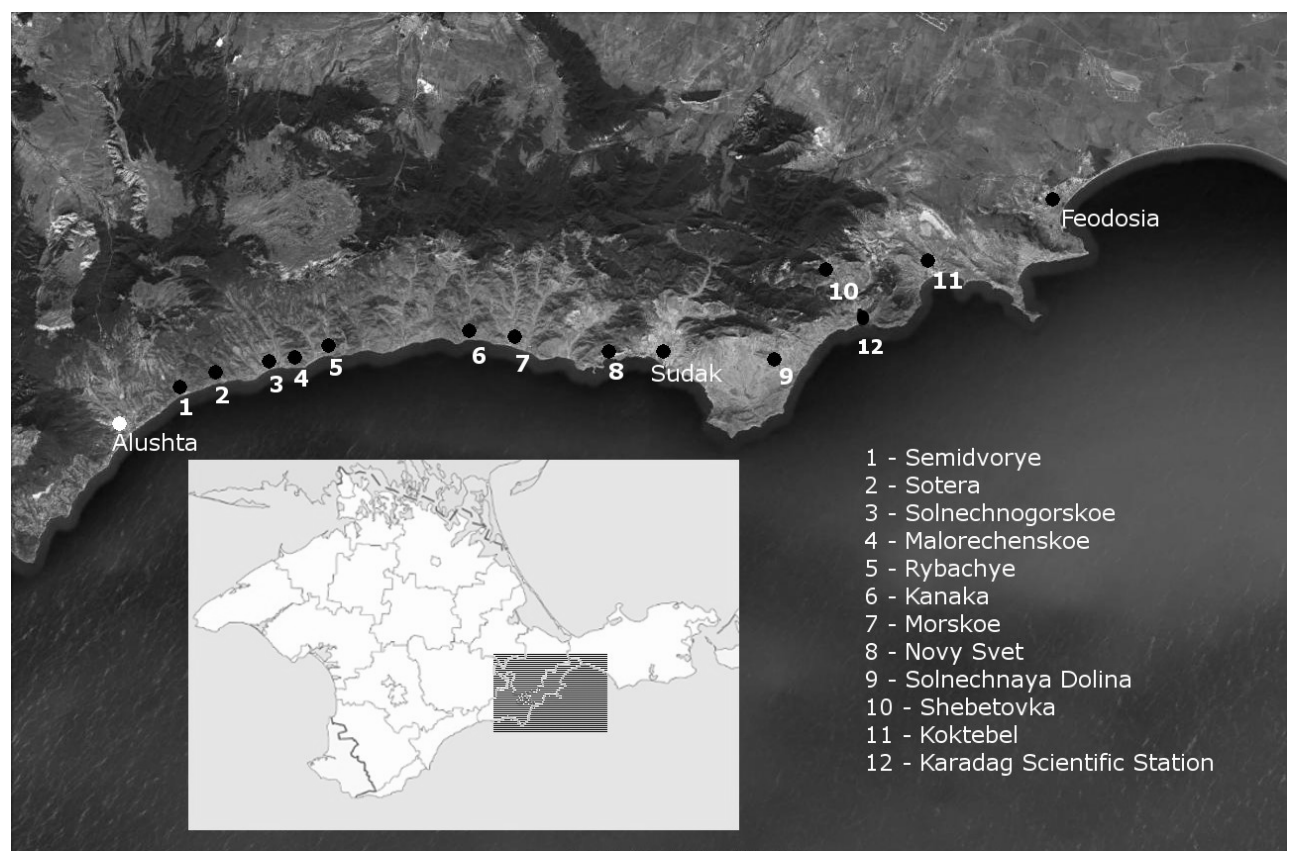

Fig. 1. The research area. 
In every green zone we determined diversity of species, age of the plants, estimate their state (good or bad growth), how they counteract the deleterious effect of summer drought and winter low temperatures, damage (or not) by insect pests. Age of the plants was determined according to their taxation characteristics (height, tree trunk diameter), structure and color of bark and branches. In some cases we used special method of determination the tree age [6]. The ability of introduced plants to tolerate adverse weather and climate conditions (drought, frosts, hard winds, etc.) was assessed based on our own observations and data of other researchers. Providing our investigations and giving recommendations we take into account trends of modern landscape gardening and studies of colleagues [7-10].

The investigation has been providing since 2002 year. At present work we show the results of 2017-2019 period.

\section{Results and discussion}

The heyday of planting of greenery in the region took place in the Soviet period (50-80s of the XXth century). Almost all territory of the South-East Coast was developing as a recreation area. At that time a great number of recreational complexes were built and every of them had broad parks or green zones. They were created in "nature" stile which emphasizes the beauty of the surrounding landscapes. Great attention was paid to greenery of towns and villages and their green areas became the extension of local landscape (Fig. 2).

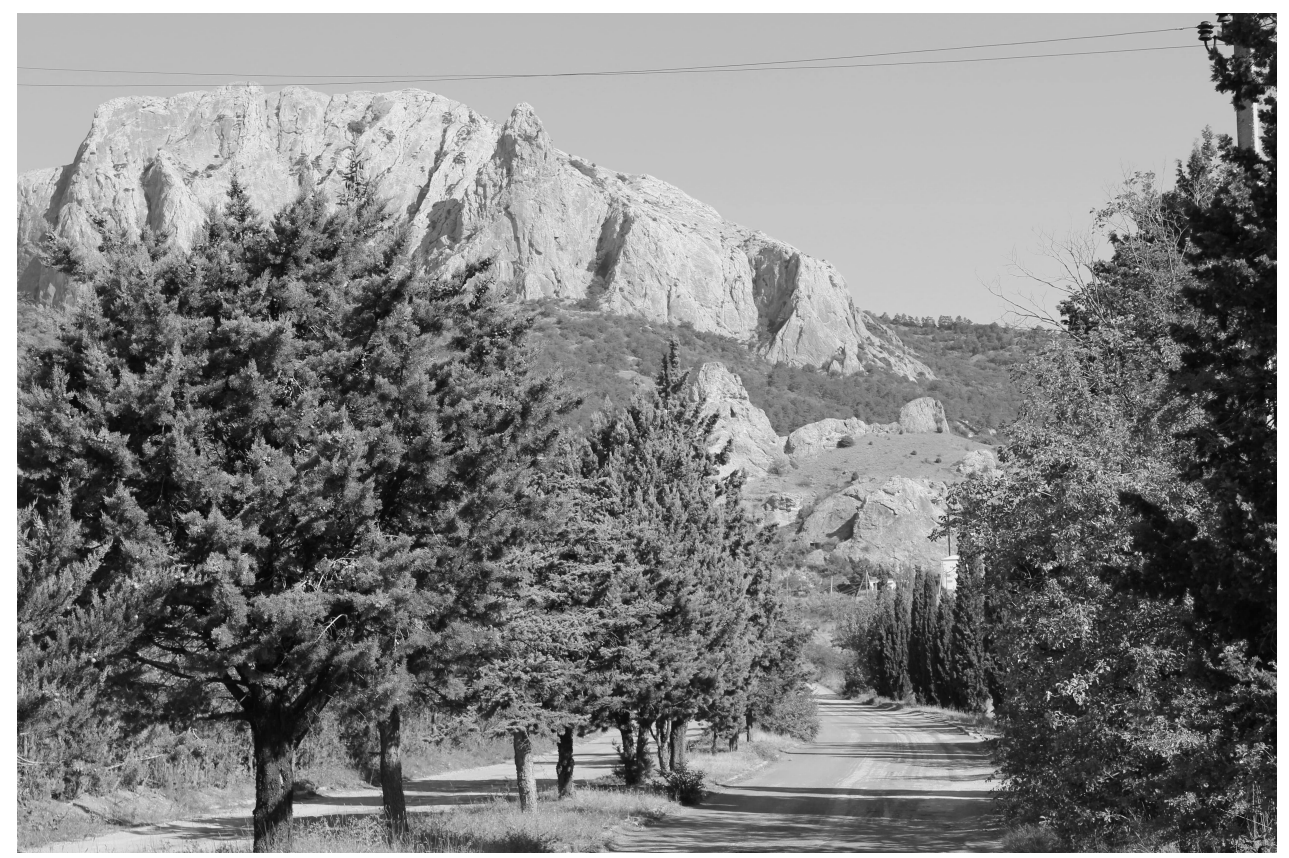

Fig. 2. Green area at the entrance of Solnechnaya Dolina (Cupressus arizonica Greene, and C. sempervirens).

The assortment of trees and shrubs was selected in accordance with specifics of the local soil and climatic conditions. In many cases works were carried out under the guidance of scientific staff of the NBG. Wonderful parks were created at health resorts and rest houses in Semidvorye, Sotera, Kanaka, Rybachye, Sudak, Morskoe, Koktebel. Many of them were not inferior in beauty and species diversity of the arboreal flora the South Coast 
parks [11]. According to special government program planting of greenery was carried out in all settlements. Thus age of the most trees is 40-60 years.

Cultivated dendroflora of the South-East Coast region totals 229 species belonging to 107 genus and 27 families of Pinophyta and Magnoliophyta (Table 1).

Table 1. Taxonomic structure of cultivated trees and shrubs.

\begin{tabular}{|c|c|c|c|}
\hline Family & $\begin{array}{c}\text { Number of } \\
\text { genus }\end{array}$ & Genus & $\begin{array}{c}\text { Number of } \\
\text { species }\end{array}$ \\
\hline \multicolumn{4}{|c|}{ Pinophyta } \\
\hline Ginkgoaceae & 1 & Ginkgo & 1 \\
\hline \multirow{8}{*}{ Cupressaceae } & \multirow{8}{*}{8} & Calocedrus & 1 \\
\hline & & Chamaecyperis & 2 \\
\hline & & Cryptomeria & 1 \\
\hline & & Cupressus & 4 \\
\hline & & Juniperus & 5 \\
\hline & & Platycladus & 1 \\
\hline & & Sequoiadendron & 1 \\
\hline & & Thuja & 1 \\
\hline \multirow{5}{*}{ Pinaceae } & \multirow{5}{*}{5} & Abies & 3 \\
\hline & & Cedrus & 3 \\
\hline & & Picea & 2 \\
\hline & & Pinus & 5 \\
\hline & & Pseudotsuga & 1 \\
\hline Taxaceae & 1 & Taxus & 1 \\
\hline Sum: 4 & 15 & Sum: & 32 \\
\hline \multicolumn{4}{|c|}{ Magnoliophyta } \\
\hline \multirow{2}{*}{ Adoxaceae } & \multirow{2}{*}{2} & Sambucus & 1 \\
\hline & & Viburnum & 4 \\
\hline \multirow{3}{*}{ Anacardiaceae } & \multirow{3}{*}{3} & Cotinus & 1 \\
\hline & & Pistacia & 1 \\
\hline & & Rhus & 2 \\
\hline Apiaceae & 1 & Bupleurum & 1 \\
\hline Apocynaceae & 1 & Nerium & 1 \\
\hline Aquifoliaceae & 1 & Ilex & 1 \\
\hline Araliaceae & 1 & Hedera & 2 \\
\hline Berberidaceae & 1 & Berberis & 6 \\
\hline Betulaceae & 1 & Betula & 1 \\
\hline \multirow{2}{*}{ Bignoniaceae } & \multirow{2}{*}{2} & Campsis & 1 \\
\hline & & Catalpa & 2 \\
\hline \multirow{2}{*}{ Buxaceae } & \multirow{2}{*}{2} & Buxus & 2 \\
\hline & & Sarcococca & 1 \\
\hline Cannabaceae & 1 & Celtis & 2 \\
\hline \multirow{4}{*}{ Caprifoliaceae } & \multirow{4}{*}{4} & Abelia & 1 \\
\hline & & Lonicera & 9 \\
\hline & & Symphoricarpos & 2 \\
\hline & & Weigela & 1 \\
\hline Celastraceae & 1 & Euonymus & 1 \\
\hline Cornaceae & 1 & Cornus & 1 \\
\hline Ebenaceae & 1 & Diospyros & 3 \\
\hline Elaeagnaceae & 1 & Elaeagnus & 1 \\
\hline Ericaceae & 1 & Arbutus & 2 \\
\hline \multirow{2}{*}{ Fagaceae } & \multirow{2}{*}{2} & Castanea & 1 \\
\hline & & Quercus & 6 \\
\hline
\end{tabular}




\begin{tabular}{|c|c|c|c|}
\hline \multirow{3}{*}{ Hydrangeaceae } & \multirow{3}{*}{3} & Deutzia & 1 \\
\hline & & Hydrangea & 1 \\
\hline & & Philadelphus & 1 \\
\hline Juglandaceae & 1 & Juglans & 2 \\
\hline \multirow{3}{*}{ Lamiacea } & \multirow{3}{*}{3} & Caryopteris & 1 \\
\hline & & Rosmarinum & 1 \\
\hline & & Vitex & 1 \\
\hline Lauraceae & 1 & Laurus & 1 \\
\hline \multirow{9}{*}{ Leguminosae } & \multirow{9}{*}{9} & Albizzia & 1 \\
\hline & & Cercis & 1 \\
\hline & & Colutea & 2 \\
\hline & & Gleditsia & 1 \\
\hline & & Laburnum & 1 \\
\hline & & Robinia & 2 \\
\hline & & Styphnolobium & 1 \\
\hline & & Spartium & 1 \\
\hline & & Wisteria & 1 \\
\hline \multirow{2}{*}{ Lythraceae } & \multirow{2}{*}{2} & Lagerstroemia & 1 \\
\hline & & Punica & 1 \\
\hline Magnoliaceae & 1 & Magnolia & 1 \\
\hline Malvaceae & 1 & Hibiscus & 1 \\
\hline Meliaceae & 1 & Melia & 1 \\
\hline \multirow{4}{*}{ Moraceae } & \multirow{4}{*}{4} & Broussonetia & 1 \\
\hline & & Ficus & 1 \\
\hline & & Maclura & 1 \\
\hline & & Morus & 2 \\
\hline \multirow{7}{*}{ Oleaceae } & \multirow{7}{*}{7} & Forsythia & 1 \\
\hline & & Fraxinus & 4 \\
\hline & & Jasminum & 2 \\
\hline & & Ligustrum & 2 \\
\hline & & Olea & 1 \\
\hline & & Phillyrea & 2 \\
\hline & & Syringa & 1 \\
\hline Pittosporaceae & 1 & Pittosporum & 2 \\
\hline Platanaceae & 1 & Platanus & 3 \\
\hline Ranunculaceae & 1 & Clematis & 2 \\
\hline Rhamnaceae & 1 & Paliurus & 1 \\
\hline \multirow{16}{*}{ Rosaceae } & \multirow{16}{*}{16} & Chaenomeles & 2 \\
\hline & & Cotoneaster & 9 \\
\hline & & Crataegus & 8 \\
\hline & & Cydonia & 1 \\
\hline & & Eriobotrya & 1 \\
\hline & & Exochorda & 1 \\
\hline & & Malus & 3 \\
\hline & & Padus & 1 \\
\hline & & Photinia & 1 \\
\hline & & Prunus & 11 \\
\hline & & Pyracantha & 1 \\
\hline & & Pyrus & 2 \\
\hline & & Rhodotypus & 1 \\
\hline & & Rosa & 3 \\
\hline & & Sorbus & 5 \\
\hline & & Spiraea & 4 \\
\hline Salicaceae & 1 & Salix & 4 \\
\hline
\end{tabular}




\begin{tabular}{|l|c|l|c|}
\hline \multirow{3}{*}{ Sapindaceae } & \multirow{2}{*}{3} & Acer & 5 \\
\cline { 3 - 4 } & & Aesculus & 2 \\
\cline { 3 - 4 } & & Koelreuteria & 1 \\
\hline Scrophulariaceae & 1 & Buddleja & 2 \\
\hline Simaroubaceae & 1 & Lycium & 1 \\
\hline Solanaceae & 1 & Tamarix & 1 \\
\hline Tamaricaceae & 1 & Tilia & 3 \\
\hline Tiliaceae & 1 & Ulmus & 3 \\
\hline Ulmaceae & 2 & Vitis & 1 \\
\cline { 3 - 4 } & & Parthenocissus & 1 \\
\hline Vitaceae & 92 & Sum: 92 & 229 \\
\hline Sum: 43 & 107 & Total: & 29 \\
\hline Total: 47 & &
\end{tabular}

Pinophyta occupies $4(8,5 \%)$ families, $15(14,0 \%)$ genus, $32(14,0 \%)$ species. The leading role in Pinophyta belongs to Cupressaceae - $16(50,0 \%)$ species of $8(53,3 \%)$ genus. The most representative genus are Juniperus and Pinus (5 species each).

Magnoliophyta occupies 43 (91,5\%) families, 92 (86,0\%) genus, 197 (86,0 \%) species. The leading role in Magnoliophyta belongs to families: Rosaceae - 54 (27,4 \%) species of $16(17,4 \%)$ genus; Oleaceae - $13(6,6 \%)$ species of $7(7,6 \%)$ genus; Leguminosae -11 $(5,6 \%)$ species of $9(9,8 \%)$ genus. The most representative genus are: Prunus (11species), Cotoneaster (9 species), Lonicera (9species), Crataegus (8 species), Quercus (6 species). Analysis of their bioecological characteristics has shown that they are well adapted to regional soil and climatic conditions so can be considered promising for introduction. Trees and shrubs of Rosaceae family (especially from genus Chaenomeles, Crataegus, Cotoneaster, Cydonia, Prunus, Rosa, Spiraea) are very popular in all types of green areas and mostly cultivated because of their ornamental flowering.

We analyzed the botanical-geographical origin of cultivated arboreal flora. The Crimea has close floristic connections with Mediterranean, especially its mountainous part, where the Mediterranean elements are mainly concentrated. So it is evident, that the largest number $(72$, or $31,4 \%$ ) of cultivated arboreal plants are of Mediterranean origin. The most xerophytic introduced representatives are well adapted to the soil and climatic conditions of the South-East Crimea. The only obstacle to transfer subtropical plants is the low temperature of the local winters, which is detrimental to some previously introduced species. Species of the Mediterranean flora are not only of great importance for the region as well adapted, but also because they give the cultural landscape "Mediterranean" appearance: Cedrus atlantica (Endl.) Manetti ex Carrièr, $C$. libani, Cupressus sempervirens, Prunus laurocerasus L., Laurus nobilis, Rosmarinus officinalis L., Nerium oleander L., Olea europaea L., Pinus brutia, P. pinea L., Platanus orientalis $\mathrm{L}$.

Cultivated dendroflora of the region has a rather large number $(34$, or $14,8 \%)$ of species of the Irano-Turanian floristic region. They are widely used as ornamental and fruit plants since ancient times, such as: Prunus duclis (Mill.) D.A.Webb., Ficus carica L., Morus nigra L. Many Cotoneaster species with well adaptation for local conditions have IranoTuranian origin as well. In general, trees and shrubs from the Irano-Turanian floristic region were well acclimatized. All of them are of interest for greenery and forestry, as well as fruit crops. Most of arboreal plants (32 species, or 14,0 \%) of Eastern Asiatic floristic origin are also well adapted for local conditions and grow in parks, squares, streets of towns, villages, such trees as: Ailanthus altissima (Mill.) Swingle, Koelreuteria paniculata Laxm., Platycladus orientalis, Styphnolobium japonicum (L.) Schott, and shrubs: Chaenomeles japonica (Thunb.) Lindl. ex Spach, C. speciosa (Sweet) Nakai, Deutzia scabra Thunb., Euonymus japonicus Thunb., Jasminum nudiflorum Lindl., $L$. 
fragrantissima Lindl. \& J. Paxton, Lonicera japonica Thunb. Some species of North American flora are wide spread in the region: Robinia pseudoacacia L., Gleditsia triacanthos L., Juniperus virginiana L., Catalpa speciosa Ward., C. begnonioides Walt., Campsis radicans (L.) Seem. They are in good state, but in extremely drought period catalpa trees suffer from it and need watering.

Species of native Crimean flora (67 species, or 29,3\%), being cultivated in different green areas are of special interest because of their ornamental and bioecological properties that are suit for climatic and soil conditions of the region. Talking about Crimean flora we take into account its dividing to archaeophytes and neophytes.

Archaeophytes often used in greenery: coniferous trees - Juniperus excelsa M. Bieb., $J$. sabina L., Pinus brutia, P. nigra J.F. Arnold subsp. pallasiana (Lamb.) Holmboe, Taxus baccata L.; deciduous trees - Betula pendula Roth, Fraxinus angustifolia Vahl, F. excelsior L., Elaeagnus angustifolia L.; deciduous and semi-evergreen shrubs - Cornus mas L., Tamarix ramosissima Ledeb., T. tetrandra Pall. ex M.Bieb., Pyracantha coccinea M.Roem., Ligustrum vulgare L.; lianas - Hedera helix L., Clematis vitalba L.

Neophytes often used in greenery: coniferous trees - Cedrus atlantica, Cupressus sempervirens, Platycladus orientalis; deciduous trees - Ailanthus altissima, Prunus duclis, Cydonia oblonga Mill., Juglans regia L., Morus alba L., Robinia pseudoacacia; deciduous shrubs: Lycium barbatum L., Spartium junceum L., Syringa vulgaris L.; evergreen shrubs Berberis aquifolium (Pursh) Nutt., Prunus laurocerasus (everywhere); Laurus nobilis, Rosmarinus officinalis, Viburnum tinus L. (in the west part of the region).

All plants of natural flora are in good state: they do not suffer from winter frost and summer drought, grow well, and fully demonstrate their ornamental qualities, used both in recreational complexes and urban landscaping. Ornamental native trees provide a basic contact of cultural landscapes with local nature and heighten pleasure to human surroundings. More over in some cases native vegetation fragments are the parts of cultural landscapes connecting beauty of native vegetation with urban or recreational areas [12]. At the territories of recreational complexes in Semidvorye, Kanaka, Sotera, Novy Svet there are many trees of rare, endemic and protected Crimean flora: Juniperus deltoides, J. excelsa, J. sabina, Pinus brutia, Pistacta mutica, Taxus baccata, and they are in good state (Fig. 3). Such complexes are the reserves of valuable, rare, endemic plants of the Crimean natural flora.

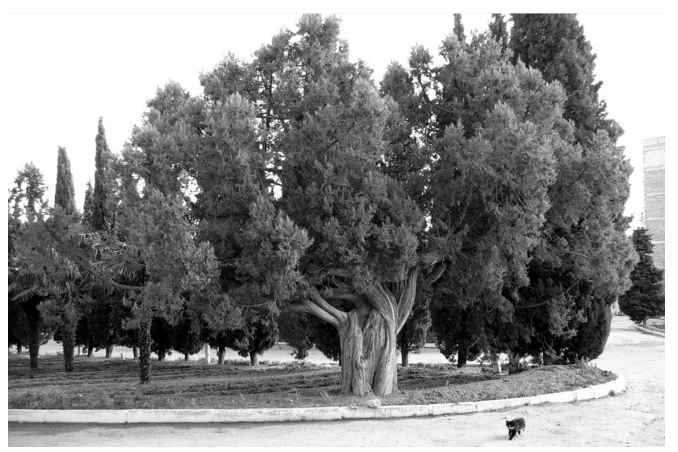

a)

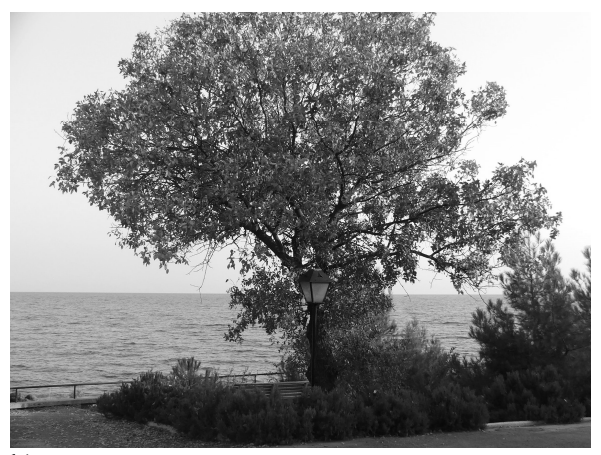

b)

Fig. 3. Species of Crimean flora (Red book of the Republic of Crimea) in landscape compositions: a) Juniperus excelsa (to the fore) in Kanaka; b - Pistacia mutica in Sotera.

More than a half $(62,9 \%)$ of the species diversity are deciduous trees $88(38,4 \%)$ and shrubs $56(24,5 \%)$. The proportion of evergreen plants is lower: coniferous trees $31(13.5$ $\%)$, evergreen deciduous shrubs $30(13,1 \%)$; the share of the other biomorphs is insignificant. 


\section{Deciduous trees}

Virtually all species of temperate broad-leaved trees are important landscape and ornamental plants and fulfill one or more functions in landscape design. One of the major purposes of trees in the region is to provide shade in extremely hot summer period. Many temperate broad-leaved trees characteristically have spreading crowns, dense foliage and provide excellent shade around homes, schools, hospitals, places of work, along streets and highways, in city parks, and other areas [13]. Planting of trees along roadsides in towns and cities provides not only welcome shade on warm summer days, but they also soften touch of the sun of homes, office buildings, factories and other structures. The most popular shade trees are species of Platanus, Fraxinus as well as Aesculus hippocastanum, Styphnolobium japonicum, Robinia pseudoacacia, Albizzia julibrissin Durazz. Trees of Platanus do not only provide good shade, but also their flaky light-green, light-grey and grey bark is attractive in all seasons of the year. It is a popular tree for planting along streets, city squares and parks. Very good examples of using plane-trees in greenery are in Feodosia, Sudak, Solnechnaya Dolina, Kanaka, Semidvorye (Fig. 4). Species of genus Celtis (Celtis australis L., C. glabrata Stev. ex Planch.), Quercus (Quercus pubescens, Q. serrata Murray), Tilia (Tilia begonifolia Stev., T. cordata Mill.) are not so popular though give a good shade and are well adapted for the local conditions, thus should be grown more often.

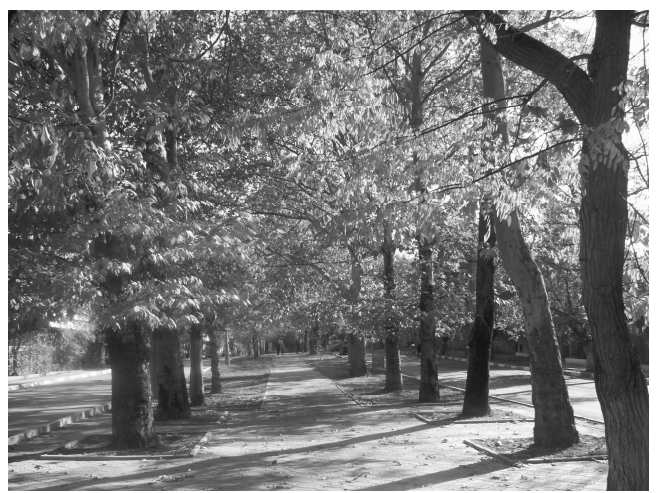

a)

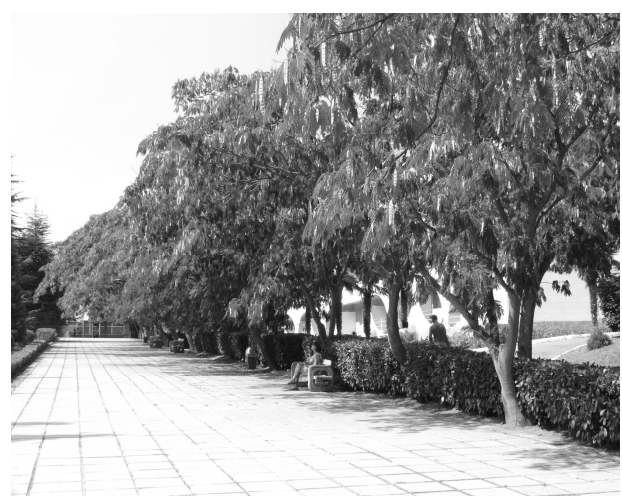

b)

Fig. 4. Broad-leaved shade trees in green planting: a) Platanus acerifolia Willd., $P$. orientalis in Feodosia; b) Albizzia julibrissin in Semidvorye.

Flowering trees are especially popular: Cydonia oblonga, Malus niedzwetzkyana Dieck ex Koehne, M. × purpurea (E.Barbier) Rehder, Prunus armeniaca L., P. cerasifera Ehrh., $P$. duclis, P. mahaleb L., P. persica (L.) Batsch., those typically produce white and pink blossoms in spring before leafing out.

Brilliant foliage color during the autumn season is another desirable characteristic of landscape and ornamental trees. Many deciduous broad-leaved trees produce brilliant displays of fall color. For example, Diospyros kaki Thunb., Fraxinus angustifolia, $F$. excelsior, Koelreuteria paniculata, Pistacia mutica. Some trees have one-color, but bright and clear coloring (usually yellow, golden): Morus alba, Ginkgo biloba L., Fraxinus americana L. Autumn color of foliage is not constant from year to year, it changes under the influence of environmental conditions. If autumn is lingering and warm, coloring foliage persists on plants for a longer period. Rains and early cooling shorten the duration of the autumn decoration of arboreal plants. Accelerate the beginning of leaf fall strong winds that are frequent in this region in October and November. 


\section{Deciduous shrubs}

Deciduous shrubs are dynamic, changing with the seasons and often providing fresh spring foliage, flowers, fruits and autumn leaf color. Flowering deciduous shrubs are often used in landscape gardening [14]. Some of them are extraordinary decorative in early spring when produce abundant flowers before leafing out: Cornus mas, Chaenomeles japonica, $C$. speciosa, Exochorda racemosa (Lindl.) Rehder, Forsythia europaea Degen \& Bald., Cercis siliquastrum L., Prunus spinosa L., Tamarix tetrandra. Some of them bloom in summer during peak of recreation season giving pleasure to resting people: Abelia grandiflora (Ravelli ex Andre) Rehder, Buddleja davidii Franch., Hibiscus syriacus L. Another desired trait for greenery is bushes that produce flowers in spring and brightly colored but not necessarily edible fruits later in the season. A good example is species of Cotoneaster, Crataegus, Lonicera fragrantissima, L. xylosteum L. which typically produce white blossoms in spring and brilliant red fruits in autumn.

\section{Coniferous trees}

In landscape architecture of the Crimea and in the South-East Crimea in particular, coniferous plants occupy a leading place. There are a number of reasons for their widespread use: biological, ecological, historical and cultural. They are resistant, durable, attractive in all seasons of the year, have many decorative forms (cultivars). Coniferous plants play soil-protective, water-protecting and sanitary-hygienic role, softening the local climate, decorating the landscape, saturating the air with oxygen and purifying it with volatile products. Many introduced conifers: cypresses, cedars, pine trees firmly entered the culture of the Crimea, became organically inherent in it, created the unique beauty of the Mediterranean landscape here. If deciduous trees have more than coniferous species diversity in the region they are inferior to them by the number of plants. For example, in park of recreational complex we see some trees of ash and plane trees, chestnuts, acacia and others and at the same time tens and even hundreds of cedars, cypresses, thuja trees. Coniferous those very often grow in different types of green areas: Cedrus atlantica, Cupressus arizonica, C. sempervirens, Juniperus excelsa, J. sabina, J. virginiana, Pinus brutia, Picea pungens Engelm., P. nigra subsp. pallasiana, Platycladus orientalis, Taxus baccata, and such species as Cedrus deodara and Pinus pinea are rather often in the west part of the region.

\section{Evergreen deciduous trees}

Evergreen deciduous trees and shrubs are mostly concentrated in the west part of the region (from Semidvorye to Sudak). They provide year-round color, texture, some of them - a variety of fragrant flowers. Trees and shrubs that are distinguished by particularly beautiful, large flowers: Magnolia grandiflora L., Nerium oleander, Eriobotrya japonica (Thunb.) Lindl.

Only six species of evergreen deciduous trees are grown in the region (Arbutus andrachne L., A. x andrachnoides Link., Magnolia grandiflora, Olea europaea, Quercus ilex L., Eriobotria japonica) and mostly in recreational complexes. For example, the oldest Olea europaea (approximately 20 trees) are in Semidvorye; Magnolia grandiflora and Arbutus andrachne - single trees in recreational complexes; A. x andrachnoides - only in Karadag Scientific Station. In fact we marked the eastern point of cultivating Magnolia grandiflora - in Koktebel and Karadag Scientific Station; Arbutus andrachne - two trees in 
arboretum of Karadag Scientific Station. They are more than 30 years old, in good state, annually produce flowers and fruits (Fig. 5).

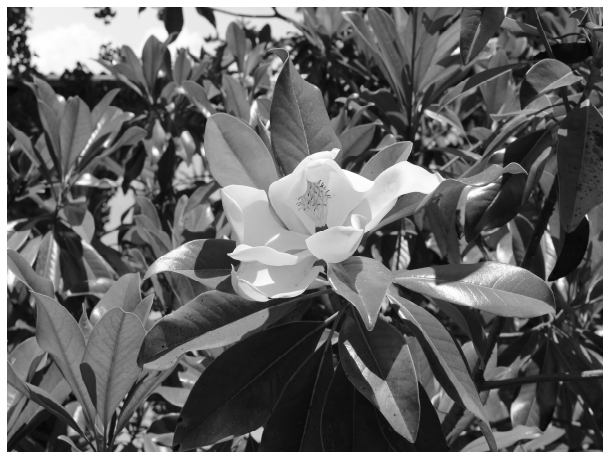

a)

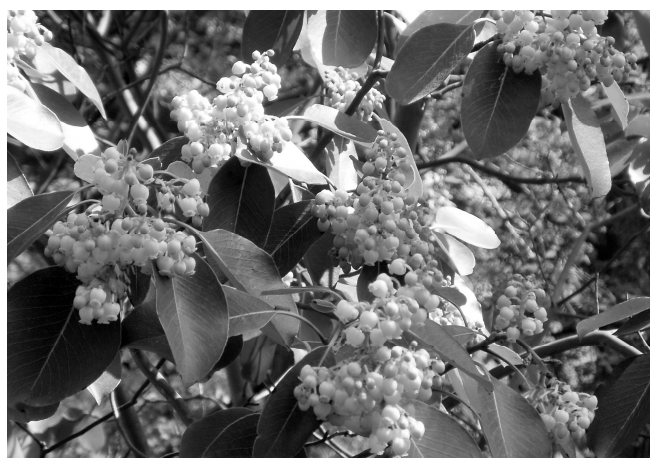

b)

Fig. 5. Magnolia grandiflora (a) and Arbutus andrachne (b) in arboretum of Karadag Scientific Station.

\section{Evergreen and semi-evergreen shrubs}

Evergreen and semi-evergreen shrubs offer year round interest in the garden. Threy tolerate more wide range of growing conditions than evergreen trees. So they grow numerously in small and large groups, green fence: Berberis aquifolium, Prunus laurocerasus, Buxus sempervirens, Pyracantha coccinea, Cotoneaster salicifolius Franchet, Euonymus japonicus, Bupleurum fruticosum L., Pittosporum heterophyllum Franch., Viburnum rhytidophyllum Hemsl. (everwhere), and Laurocerasus lusitanica (L.) Roem., Ligustrum lucidum W.T.Aiton, Viburnum tinus, Nerium oleander (in the west part of the region). Evergreens are static in comparison. They also blend well into mixed borders, with varieties from knee height to small trees - in fact, many can be shaped to fulfill this role (Fig. 6).

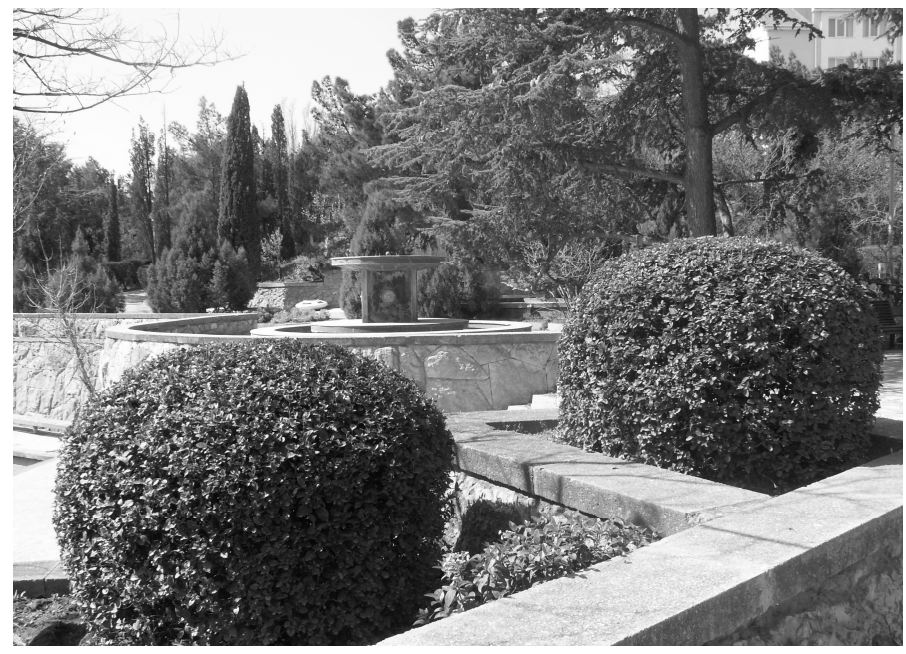

Fig. 6. Composition with shaped Viburnum tinus in landscape art park-monument of local significance of the tourist-recreational complex "Sudak".

In modern landscape gardening many different cultivars are being used. They help to form different composition to create a specific emotional state. Cultivars differ from the species in morphological characteristics - the shape of the crown, the size and color of 
flowers, leaves, fruits. In green areas of the South-East of the Crimea different cultivars of trees and shrubs are presented but their diversity is small-scale and their participation in landscape design is insignificant. An exception is the pyramidal forms of cypress (Cupressus sempervirens 'Pyramidalis', 'Australis', 'Indica') used everywhere and is the symbol of the Crimea.

Some weeping forms with long branches grow in Sudak, Feodosia: Morus alba 'Pendula', Styphnolobium japonicum 'Pendula'. Rather usual such cultivars as: Viburnum opulus 'Roseum', Aucuba japonica 'Variegata', Cedrus atlantica 'Glauca', Cupressus arizonica 'Truncis pluribus', Picea pungens 'Glauca', Platycladus orientalis 'Globosa', Taxus baccata 'Fastigiata', T. b. 'Stricta'.

There are several cultivars in arboretum of Karadag Scientific Station those should be used in green areas, especially in parks of recreational complexes because of their ability to grow and survive under a range of climatic and soil conditions of the region. With unusual flowering are: Crataegus monogyna 'Rosea-plena', Buddleja $\times$ weyeriana 'Sungold', Deutzia $\times$ hybrida 'Strawberry fields', D. scabra 'Candidissima', Kerria japonica 'Pleniflora', Weigela $\times$ hybrida 'Brystol Ruby', Hydrangea arborescens 'Grandiflora'; with untypical for species leaves: Symphoricarpos orbiculatus 'Variegatus', Kerria japonica 'Picta', Sambucus nigra 'Laciniata'. They will be useful for landscape design of local cultural cenosis.

In the Mediterranean region, historically man has profoundly modified the natural environment producing combinations of different types of vegetation, varying from intensively cultivated fields to almost natural forest tree. Human influence on natural landscapes is very significant. So providing introductive works it should be taken into account the ability of some plants to rapidly reproduce and effect the invasions, such as occurs with Opuntia (O. humifusa (Raf.) Raf., O. phaeacantha var. camanchica (Engelm. \& J.M. Bigelow) L.D. Benson) and Ailanthus altissima. The problem of plant invasion has becoming more and more current in the Crimea and other regions as well [15-17].

A wide variety of pests and diseases affect ornamental trees and shrubs. At present the mass insect pests that cause significant damage of ornamental trees and shrubs on the South-Eastern coast of the Crimea are Cydalima perspectalis Walker (for Buxus) and Cameraria ohridella Deschka \& Dimiê (for Aesculus hippocastanum). Invasion of Cydalima perspectalis to the Crimea is a catastrophic example of the loss of a highly valued group of evergreen shrub as in many places Buxus sempervirens is consumed. Cameraria ohridella invade feed plants are affected, but no deaths of trees have been noted.

\section{Conclusions}

Cultivated dendroflora of the South-East Costal region totals 229 species belonging to 107 genus of 27 families. Pinophyta occupies $14,0 \%$ of species diversity. The leading role belongs to Cupressaceae $-50,0 \%$ species. The most representative genus are Juniperus and Pinus (5 species each). Magnoliophyta occupies $86,0 \%$ species. The leading role belongs to families: Rosaceae $-27,4 \%$ species; Oleaceae $-6,6 \%$ species; Leguminosae $5,6 \%$ species. The most representative genus are: Prunus (11species), Cotoneaster (9 species), Lonicera (9species), Crataegus (8 species), Quercus (6 species).

More than a half $(62,9 \%)$ of the species diversity are deciduous trees $(38,4 \%)$ and shrubs $(24,5 \%)$. The proportion of evergreen plants is lower: coniferous trees $-13,5 \%$, evergreen deciduous shrubs $-13,1 \%$; the share of the other biomorphs is insignificant. One of the major purposes of trees in the region is to provide shade in extremely hot summer period by such species as: Aesculus hippocastanum, Styphnolobium japonicum, Robinia pseudoacacia, Albizzia julibrissin, Platanus acerifolia, P. orientalis, Fraxinus excelsior. Evergreen plants (both coniferous and deciduous) are attractive in all seasons of the year, 
decorating the landscape, saturating the air with oxygen and purifying it with volatile products. The most popular are: Cedrus atlantica, Cupressus arizonica, C. sempervirens, Juniperus excelsa, J. sabina, J. virginiana, Pinus brutia, P. nigra subsp. pallasiana, Picea pungens, Platycladus orientalis, Taxus baccata.

Cultivated dendroflora of the South-East Coast has close floristic, historical and cultural connections with the Mediterranean region. The largest number (72, or 31,4 \%) of cultivated arboreal plants are of Mediterranean origin. Species of native Crimean flora (67 species, or 29,3\%) being cultivated in different green areas are of special interest because of their adaptation for climatic and soil conditions of the region. It should be taken into account when creating parks and other green areas. The assortment of ornamental trees and shrubs should correspond to the chosen style as well. Their ability to withstand summer drought and winter low temperatures is a factor that must be considered.

\section{Acknowledgements}

The work was supported by the research project of T.I. Vyazemsky Karadag Scientific Station - Nature Reserve of RAS - Branch of A.O. Kovalevsky "Institute of Biology of the Southern Seas of RAS” (№ AAAA-A19-119012490044-3).

\section{References}

1. C.E. Cordova, Méditerranée 126, 25-36 (2016) doi: 10.4000/mediterrance

2. C.E. Cordova, Crimea and the Black Sea: An Environmental History (London, I.B. Tauris, 2016)

3. P.S. Hnativ, N.J. Lopotych, B.I. Parkhuts, O.V. Haskevych, N.I. Veha, Ukrainian Journal of Ecology 10(1), 151-157 (2020) doi: 10.15421/2020_24

4. F. Lisetskii, E. Ergina, Eurasian Soil Science 43(6), 601-613 (2010) doi: 10.1134/S1064229310060013

5. P. Lionello, The Climate of the Mediterranean Region. From the past to the future (Elsevier, 2012) doi: 10.1016/C2011-0-06210-5

6. J.V. Plugatar, Nature Reserve 2, 122-148 (2011)

7. J.V. Plugatar, V.P. Koba, V.N. Gerasimchuk, V.V. Papelbu, International Symposium on Horticulture: Priorities \& Emerging Trends (2017)

8. B.I. Kochurov, Y.A. Khaziakhmetova, I.V. Ivashkina, E.A. Sukmanova, South of Russia: ecology development 13(3), 72-82 (2018) doi: 10.18470 / 1992-1098-3-71-82

9. T.O. Boiko, O.I. Dementieva, Ukrainian Journal of Ecology 8(2), 120-127 (2018) doi: 10. $15421 / 2018-318$

10. J.V. Plugatar, Z.K. Klimenko, I.V. Ulanovskaya, V.K. Zykova, S.A. Plugatar, Acta Horticulture 1240, 65-68 (2019) doi: 10.17660/ActaHortic.2018.1201.68

11. I.L. Potapenko, N.I. Klimenko, V.Yu. Letukhova, South of Russia: ecology development 12(3), 64-74 (2017) doi: 10.18470/1992-1098-2017-3-64-74

12. M.N. Peterson, B. Thurmond, M. Mchale, S. Rodrigues, H.D. Bondell, M. Cook, Sustainable Cities and Society 5, 70-76 (2012) doi:10.1016/j. ses. 2012. 05.007

13. A.P.R. Jeanjean, R. Buccolieri, J. Eddy, P.S. Monks, R.J. Leigh, Urban Forestry \& Urban Greening 22, 41-53 (2017) doi: 10.1016/j.ufug.2017.01.009 
14. J.V. Plugatar, V.K. Zykova, The Second Asian Hoticultural Congress Program \& Abstracts (2016)

15. C. Sîrbu, A. Oprea, C. Samuil, C. Tănase, Folia Geobotanica 47(2), 215-229 (2012) doi: 10.1007/s12224-011-9112-y

16. M. Mysliwy, Applied Ecology and Environmental Research 12(1), 193-207 (2014)

17. V.V. Fateryga, N.A. Bagrikova, Nature Conservation Research 2(4), 26-39 (2017) doi: $10.24189 /$ ncr.2017.011 